\title{
The Dynamics of Innovative Susceptibility of the Siberian Federal District Regions in the Context of the Russian Federation Innovation Development Rating in 2000-2013
}

\author{
Olga N. Vladimirova* \\ and Marina V. Malakhovskaya \\ Siberian Federal University \\ 79 Svobodny, Krasnoyarsk, 660041, Russia
}

Received 10.06.2016, received in revised form 18.07.2016, accepted 26.08.2016

There is no alternative to the innovative way of competitive stability in the open economy. Susceptibility to innovation becomes an indicator of motivation and an essential factor in the economic system growth. The effectiveness of regulation both the innovation process and innovation sector of the territorial economy determines the adequacy of the tools selected. The choice of approach to the regulation puts the focus on differences in the research methods and theoretical explanation of the phenomena of innovation as an economic good. It is possible to determine differences and peculiarities of innovative susceptibility of the Siberian Federal District through the use of statistical data (official and regional statistical reports for the SFD 2000-2013), the analytical model of innovative susceptibility of regional economy, Oslo Guidelines approach, the use of the factor approach to innovation and defining the relationship between the results of innovative activity and regional product. This analysis allows us to construct a matrix of tools for innovative management. Analytical matrix can serve as a basis for effective adaptation of innovation policy to the region's realias. The concept of tools for administrative influence from the state regional authorities is proposed on the basis of requirements in case of the presence of the "irreducible infrastructural minimum" in subject's innovative orientation. Only this composition of innovative infrastructure is capable of ensuring the flow and going through the nature of innovation. The authors offered the matrix method of the innovation policy's "target orientation". The method will provide adequate and timely reaction of innovative policy and multi-channel regulation. A model of "irreducible minimum" for the innovative sector infrastructure of the regional economy was postulated, the relation between the level of innovative susceptibility and development of the "through innovation" technological approach, as well as the possibility of the matrix approach to the form the innovation policy of the territory (continuity purposes, tools, resource, and methods) were proved.

Keywords: region's innovative susceptibility, rating list of region's innovative susceptibility, the subjects of the Siberian Federal District.

DOI: 10.17516/1997-1370-2016-9-11-2599-2615.

Research area: economics.

(C) Siberian Federal University. All rights reserved

* Corresponding author E-mail address: olga.ovladimirova24@yandex.ru 


\section{Introduction}

The possibility of innovation management is provided by taking into account the peculiarities of geographically rooted innovation system. The methods for the World Economic Forum competitiveness assessment, the European Commission (EC) methods, the methods of the Organization for Economic Cooperation and Development (OECD), the methods of the American Science Foundation (NCF) are used in the practice of the comparative analysis of countries and regions' innovativeness. The typology of the Russian regions and CIS countries in accordance with the degree of innovative potential and the scale of innovative activity development by V.L. Baburin (Baburin, 2002); the typology of innovative potential on the basis of the analysis of variance and expert analysis by N.N. Volkov and N.I. Markov (The Movement of Russian Regions..., 2006); the Russian Regional Innovative Index model (National Research University Higher School of Economics) (Rating of Innovative Development..., 2015) and the regions grouping by the innovation index method (Background Report to the OECD Country Review, 2000) can be found in the Russian literature. The SFD regions statistics, including general economic and specific one, for the period of 2000-2013 in comparison with the state of the Russian innovation indicators demonstrate a lack of level and dynamics of the innovation development indicators (Vladimirova, 2013). Thus, the share of innovative products in Russia in total production is $8-9 \%$ (in the leading countries this figure is about $15 \%$ ), and according to the data has not grown over the past 3 years, the results of Russian innovations have low competitiveness: Russia's share in the total world exports of high-tech goods is $0.4 \%$ (National Report, 2015), highlighting the need for urgent efforts to transform the regulatory mechanisms and tools for increasing connectedness and mutual supportability of the territories' innovation systems components.

\section{Theoretical Framework}

Innovative factors that give rise to a clash of principles of organization and activity-related systems formation have a significant impact on the content and results of social, including economic practices. Focus on the principle of the activity approach standards allows to "fumble" the system of the innovative sector regulatory tools through the demarcation of the stage of paradigmatization when normativity is constructed and presented, and the stage of sintagmatization, when the norm is implemented into the regulatory practices. The formation of goal achieving construction of the proposed activity requires intension between norm and diversity, making the driving contradiction of the activity-based systems. It requires establishment of not only explicit rules and regulations, but also informal ones, with internal control of activity. Assuming that the diversification of the ways of goal achieving activities implementation in actual practices has only implicit existence, the ability to express the diversity space by constructing a matrix search field for effective regulatory mechanisms, the explication of which can stimulate innovation development is regarded as a reasonable administrative use of the activity-based paradigmatics. The state of activity-based problematics and activitybased paradigm elaboration in transdisciplinary scientific knowledge has reached the stage of maturity. Neurophysiology (Anokhin, 1978), philosophy (Batishchev, 1990; Ilyenkov, 1984; Yudin, 1997), psychology (Leontiev, 1977) and sociology (Parsons, 2000) contributions are significant. In management, G.P. Shchedrovitsky (Shchedrovitsky, 2005-2008) and V.V. Davydov's (Davydov, 1996) contribution, who established activity implementation as the one existing in 
the public context in the form of instrumentality: the system of resources determined on the basis of reflection necessary for the activity implementation and mediated by the level and quality of human abilities, is essential in the development of research and projective practices of the activity approach. The impact of opportunities and differences in the ways of objectification and subjectification in the use of the activity-based tools of the separated areas of practice (Malakhovskaya, 2000) is significant.

\section{Problem statement}

The necessity to ensure sustainable development under the open economy conditions predetermines the lack of alternatives to involve innovative resource of regions and the national economy of Russia. At that, the statistics indicate that the innovation dynamics in the Russian Federation has insufficient speed to ensure economic security. Innovation activity statistics reflects the low level of technology transfer, both at national and regional levels (Vladimirova, 2015). The fact that the revenues of economic enterprise in recent years (according to the estimations) fell from $15.2 \%$ to $7.3 \%$, whereas it is the economic enterprise - a preferential method of innovation activity motion, provides additional reasoning of uncertainty and objective oscillation of the innovation segment dynamics. Available estimations for 2016 demonstrated a sharp drop in business confidence index based on the Russian industry normality, calculated by the Business Survey Laboratory of Gaidar Institute: for the $1^{\text {st }}$ quarter of 2016 the index lost 4 p.p., which is comparable only with the drop of 20082009. Weak demand (the index lost 8 p.p.) and production capacities excess (the index lost 6 p.p.) support the tendency. Enterprises continue to accumulate reserves - the proportion of normal valuations remained during 2015 , and in the $4^{\text {th }}$ quarter of 2015 reached its maximum since March
1992. The demand forecasts were the worst since 2010 - only $42 \%$ of enterprises are satisfied with its volumes. For the first time excess capacity was among the reasons - (up to $28 \%$, while only $7 \%$ of the enterprises mentioned capacity deficiency) (“Levada Center", 2016). Identifying opportunities for stimulating and supporting innovative practices is brought to the forefront of the corporate and government administrative and regulatory efforts. Innovative susceptibility, defined as the ability of economic agents of the region and governments to create and implement innovative processes as interrelated components that make up the content of innovation policy, on the basis of existing conditions and resources in accordancewithregionalandnationaldevelopment strategies, plays the most important role in increasing the pace of economic transformation in all the sectors of economy. The applied result of the innovative susceptibility monitoring and analysis (Vladimirova, 2015) becomes a tool for the innovative practices regulation and replication that can ensure effective management of the territorial innovation system at all the stages of its evolution.

\section{Methods}

The innovative susceptibility on the part of activity-based methods can be presented as an economic motivation, determined by the gains from investments into innovation, expected by the participants (Malakhovskaya, Skryl'nikova, 2009). Approaches to the assessment of innovative processes, available both in domestic and foreign publications are characterized by diversity and breadth of the list of the indicators used. The research is carried out to rationalize the benefits of management approach, which is formed on the basis of the innovative susceptibility rating. The comparison of the ratings methods and results undertaken by the authors (Russian Regional Innovation Index and the Innovative Susceptibility 
Rating (Vladimirova, 2011) allows to detect and give reasons for the influence of the selected analytical model of innovative activity on the tools and effectiveness of its (activity) expected regulation. It is obvious that a similar statistical database (official and regional statistical reports) is used in the process of the innovative susceptibility ratings and Russian Regional Innovation Index formation, a series of the similar indicators is determined by the influence of Oslo Guidelines methods, the inclusion of human, institutional and scientific and industrial factors of innovations is determined by the nature of innovation as an economic good and allows to define the impact of innovation activity result on regional product. Firstly, the degree of the factorial field detailed elaboration of innovation activity varies and it is caused by the peculiarities of theoretical model of the place of innovation in business practices and methods of the research tasks implementation. Secondly, difference in integral models emerging due to the need to consider the specificity of the established business culture of the territory that influences the place and effectiveness of the territorial innovation model components. Thirdly, the peculiarities of private indicators grouping are also determined by the differences in purposes that can be formulated as premised adequacy monitoring (Russian Regional Innovation Index) and the motivation of innovative modernization of production systems monitoring (innovative susceptibility). Monitoring design is defined by the concept of innovation activity deployment and provides an overview of the resource and results-based components, not only in the terms of GRP, but also in transforming the forms of the regional economy social practices. The resulting Matrix of the tools for innovative regulation of the SFD regions is obtained by a step by step approach through construction the Matrix of Innovative Susceptibility of the SFD Regions and Comparative Typology of the SFD
Regions' Innovative Susceptibility. A summary of the obtained space of possibilities is made in the form of the matrix of the areas of innovation policy logics formation.

\section{Discussion}

The Siberian Federal District innovative susceptibility monitoring is based on the resource and results-based indicators. When choosing management and analytical approaches human capital is of paramount importance and it is advisable to pay attention to the value of the number and density of connections that form the innovators' activities environment. The indicators dynamics reveals a relatively low level of decrease in the Tomsk and Novosibirsk regions as the leaders with the sufficient density of innovation field. The fundamental (basic) element providing the required flow of innovation activity and innovation development is the availability of the specialists who implement innovative projects (who offer and implement innovative products, production and management technologies). In this connection, an essential initial data of the analysis is the indicator of the share of employees in research and development (R\&D), reflecting the change in the innovation activity involvement motivation (as a percentage of total employment (Fig. 1).

Statistical and calculated values evidence of the preservation of the innovation tendency of decline in the share of employees in R\&D, negative for the environment quality. If in the Russian Federation in general, the value of this index varies between 1.11-1.37, in the SFD its value is twice lower. Accumulation of the number of researchers is observed in the Novosibirsk and Tomsk regions throughout the period of study. The subjects with industry specialization "animal husbandry and crop production" (Altai Republic, the Republic of Khakassia and the 


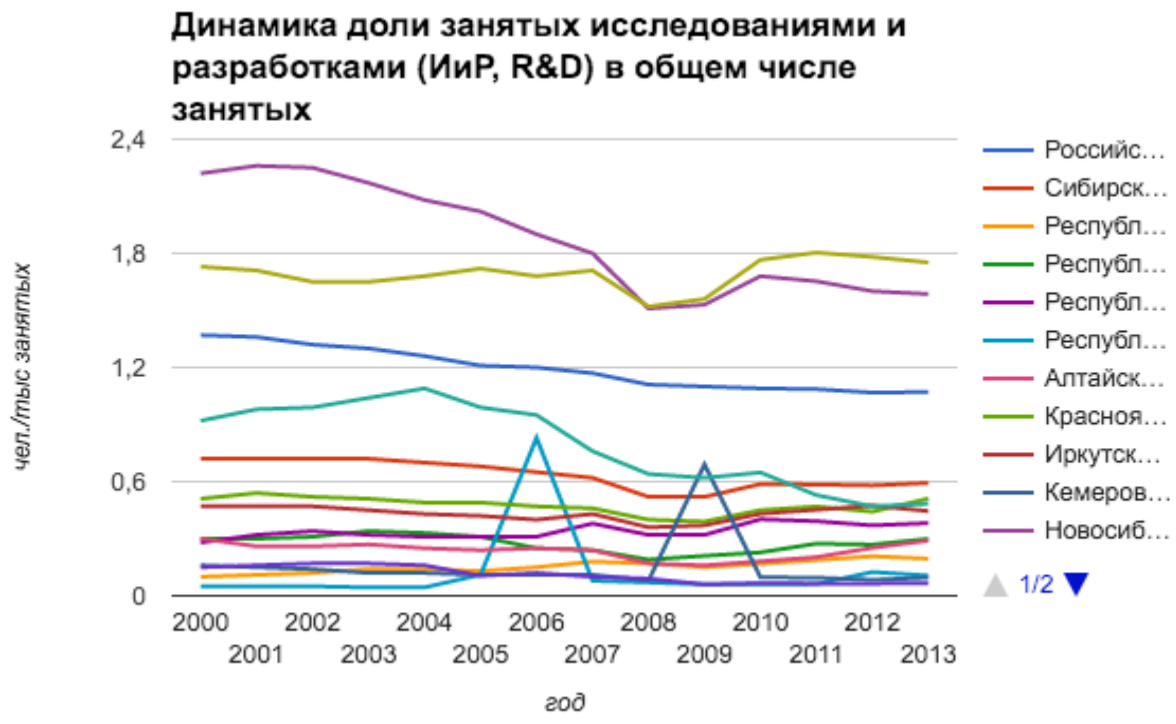

Fig. 1. Dynamics of the share of employees in research and development (R\&D) in the total number of the employed

\section{Доля инновационно активных организаций в общем их числе в СФО в \% за 2000-2013 гг.}

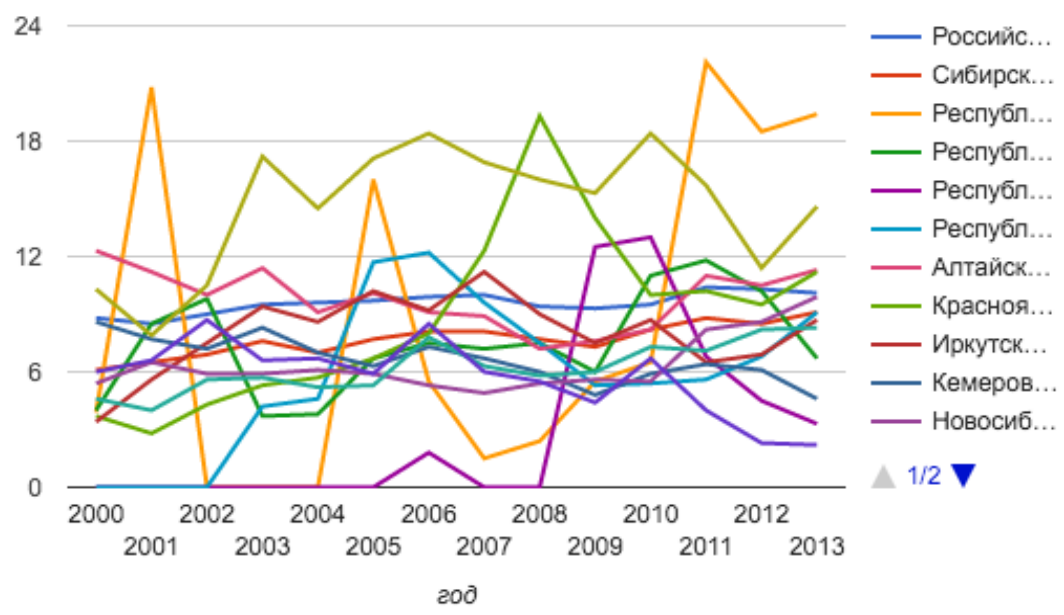

Fig. 2. The proportion of innovation-active organizations in their total number in the SFD in $\%$ for the period of 2000-2013

Republic of Buryatia) are among the outsiders. In the Krasnoyarsk Territory the index is below the average for the Russian Federation and the SFD. Interconnection in the indexes of presence and concentration of human capital, specific for innovation activity, reveals the tendencies in the dynamics of regional GRP. A proxy indicator of the concentration (density) of the employees engaged in innovation activities can be represented through the number of economic 
organizations in the territory, positioning their own practice as innovative (Fig. 2).

The vector of the proportion of innovative organizations does not have a clear focus, it is characterized by fluctuations in the period of 2000-2013 - Russia's average in the range of 8.8 $10.48 \%$, and $6.1-9.1 \%$ in the SFD. Statistical data shows that 4 subjects consistently exceed the national average. In general, in comparison with the results of previous studies, and despite the measures taken, there is no intensification in innovative activity.

Index of the innovative products, activities and services share in GDP (GRP) reflects the effectiveness of the existing innovative organizations functioning (Fig. 3).

The considered indicators demonstrate positive dynamics in the proportion of innovative products on average in Russia up to $6.4 \%$. In the SFD the share does not exceed the threshold value of $2.7 \%$. At the same time in separate subjects (the Krasnoyarsk and Trans-Baikal Territories, Novosibirsk and Omsk Regions and the Republic of Buryatia) the indicators are approaching to nationwide. Several regions have quite low levels: innovative products are scarcely produced in the Republic of Tuva and Khakassia. Thus, the intensity and effectiveness of innovation in the district in general is not sufficient for its subjects positioning in the competitive global market. Functional concentration of innovation, giving a chance for the through flow formation, capable of becoming "a link, pulling out the whole chain" of territorial economy is reflected by specific clustering: a sufficient structure formation (industry aspect) and innovation infrastructure, defining the culture of innovation. The issue of innovation infrastructure creation, operating the sphere of innovation, currently it holds leading positions in dealing with problems of innovative development of regions. Table 1 gives information on the institutional composition and quantitative parameters of the innovation infrastructure in the SFD in 2014.

Based on the provided data of registered forms, the irreducible minimum of innovative infrastructure can apparently be defined as: business incubators, centres for collective use, centres of scientific and technical information, universities, technology parks, technology transfer centers, innovation activity development centers, small business support centers, entrepreneurship support funds, SB RAS scientific centres. The issue of "irreducible minimum" elements' relations quality, the type of functions carried out by them in the local innovation system and the quality of integration into the national innovation system is definitely important. The availability of reliable data on cluster relations reality may allow to identify innovative susceptibility in three forms: "effective" - "ineffective" - "fictitious".

Effective innovation activity is possible under conditions of its provision with modern equipment and technologies (Fig. 4). The represented data reflect the absence of a common trend in the proportion of change on average in Russia despite the fact that the overall level of the indicator is estimated with low values $(0.019-0.026)$. The dynamics of indicators in the SFD is characterized by the abrupt amplitude. Novosibirsk, Tomsk and Omsk regions are at the leading positions. Only Kemerovo region and the Trans-Baikal Territory acquire less fixed assets among the SFD regions than in Russia on average. The alarming tendency of funds savings, allowing to implement innovations, is intensified under the influence of significant depreciation factors (both physical and obsolescence) of the fixed assets. The fixed assets depreciation in the Russian Federation in 2013 amounted 46.3\%, in the SFD - 40.4\%. Among the subjects of the SFD, the higher level of depreciation is in the Tomsk region $(50.6 \%)$ the Kemerovo Region (43.8\%), the Altai Territory, the Novosibirsk and Omsk regions - about 


\section{Доля инновационных товаров, работ, услуг в ВВП (ВРП) в СФО за 2000-2013rr.}

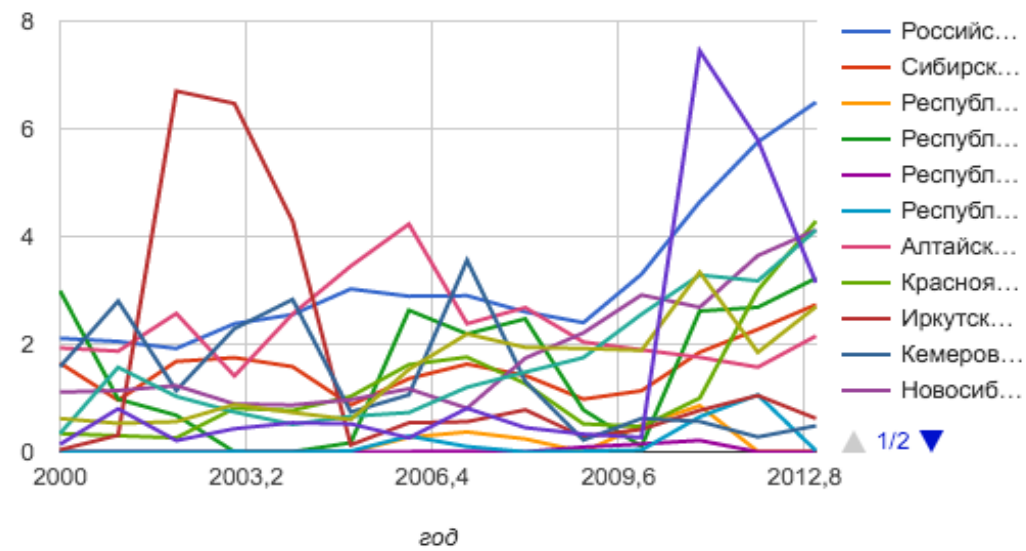

Fig. 3. The share of innovative goods, activities and services in GDP (GRP) in SFD in the period of 2000-2013

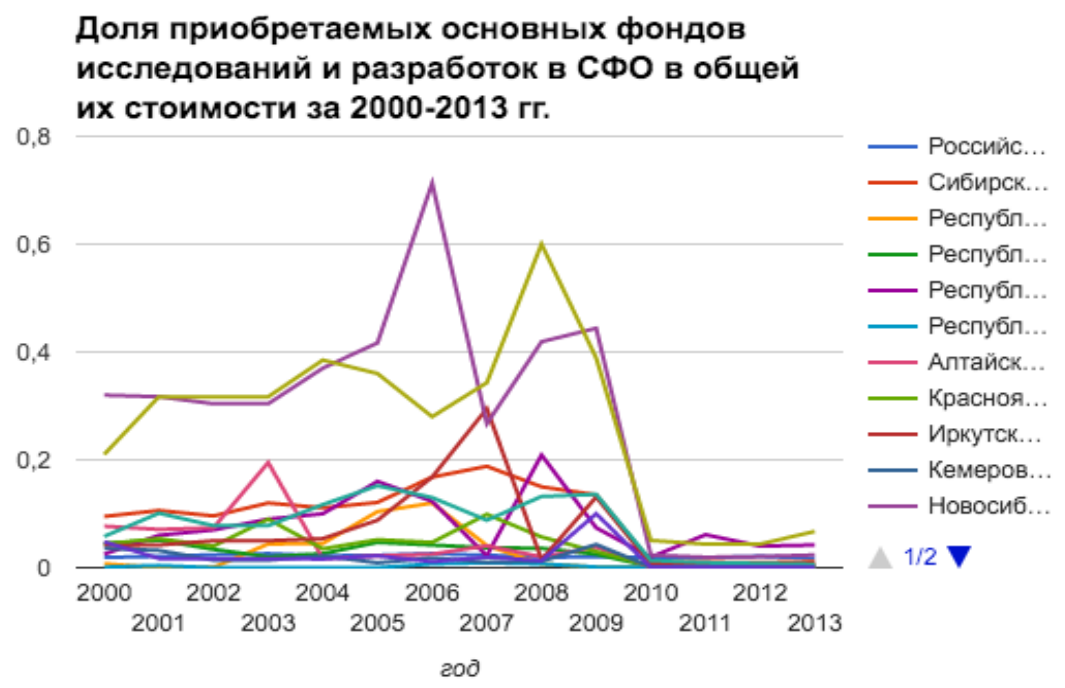

Fig. 4. The share of the acquired fixed assets for research and development in the SFD in their total value in the period of 2000-2013

$41 \%$. The range of values for the SFD $-22.4-$ $50.6 \%$ (The Regions of Russia, 2015) evidences the gravity of the situation. And the situation continues to worsen: in 2014 depreciation in Russia was already $47.9 \%-41.8 \%$ in the SFD and the dispersion was $27.2-53.4 \%$. The analysis of the statistical data changes indicates the presence of correlation between the growth of investment into the fixed assets and the change in the degree of depreciation, which is clearly illustrated by the indicators of 2010-2012. The observed dynamics of capital-labor ratio "downfall" has an effect on all the groups of innovation: technological, organizational, marketing, environmental, 


\begin{tabular}{|c|c|c|c|c|c|c|c|c|c|c|c|c|c|c|c|}
\hline [שךOL & $\vec{\sim}$ & & & - & $\infty$ & $n$ & - & ป & in & $\hat{\imath}$ & $\because$ & $=$ & $i$ & $r$ & e \\
\hline ІәЧІО & ণ & + & + & ' & 1 & 1 & 1 & 6 & & $a$ & - & & $\hat{\sim}$ & ' & $\nabla$ \\
\hline 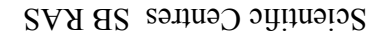 & 9 & + & + & 1 & - & 1 & 1 & ' & 1 & - & - & & - & 1 & - \\
\hline $\operatorname{spun}_{\dot{H}}$ ә.пџџ $\Lambda$ & $\infty$ & + & + & ' & 1 & 1 & 1 & 1 & 1 & - & - & & - & 1 & - \\
\hline 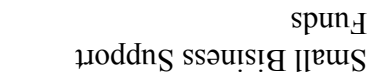 & 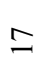 & + & + & 1 & - & 1 & 1 & - & - & 1 & $N$ & - & $\nabla$ & ' & - \\
\hline 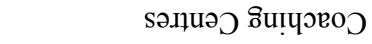 & $\stackrel{0}{-}$ & + & + & 1 & 1 & 1 & 1 & 1 & 1 & 1 & & 1 & - & 1 & 1 \\
\hline 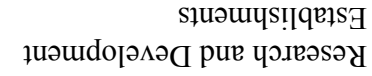 & $\cong$ & + & + & ' & 1 & 1 & 1 & $N$ & 1 & $\sim$ & & 1 & 1 & ' & 1 \\
\hline 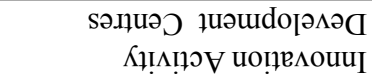 & $\Xi$ & + & + & ' & 1 & 1 & ' & 1 & ' & 1 & & 1 & $\sim$ & $'$ & $\sim$ \\
\hline 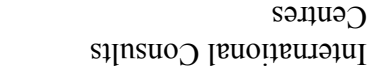 & 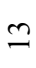 & + & + & ' & 1 & 1 & ' & ' & 1 & 1 & 1 & 1 & & ' & 1 \\
\hline 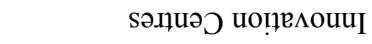 & $\simeq$ & + & + & ' & ' & 1 & ' & - & ' & & - & - & & 1 & $m$ \\
\hline 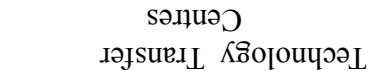 & $\exists$ & + & + & 1 & 1 & 1 & 1 & $N$ & 1 & -1 & - & - & - & 1 & $\nabla$ \\
\hline 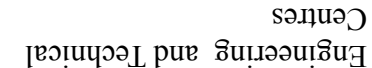 & 으 & + & + & 1 & 1 & ' & 1 & - & 1 & 1 & 1 & 1 & 6 & 1 & \\
\hline 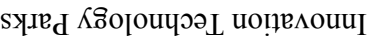 & $a$ & + & + & ' & 1 & 1 & 1 & 1 & 1 & & ' & 1 & & 1 & - \\
\hline 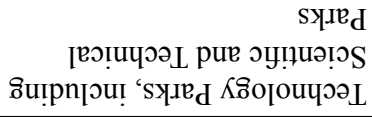 & $\infty$ & + & + & ' & 1 & - & 1 & - & - & -7 & $N$ & - & $\nabla$ & - & $\sim$ \\
\hline 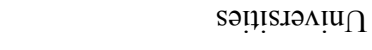 & $r$ & + & + & - & - & & - & $\sim$ & 1 & $\sim$ & - & $m$ & N & N & $\mathrm{N}$ \\
\hline S!̣odouчวəد & 6 & + & + & ' & 1 & 1 & 1 & - & ' & , & 1 & , & ' & 1 & \\
\hline 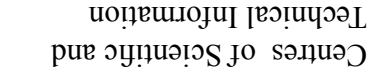 & $n$ & + & + & ' & - & 1 & 1 & - & - & -1 & - & - & - & - & - \\
\hline 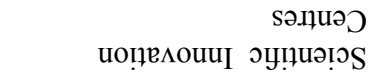 & $\nabla$ & + & + & ' & 1 & - & 1 & 1 & 1 & & 1 & I & I & 1 & \\
\hline 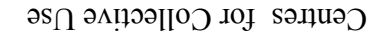 & $m$ & + & + & ' & - & 1 & 1 & $\sim$ & ' & $n$ & $N$ & - & $m$ & 1 & - \\
\hline sy.ued $_{d}$ ssouṭng & $N$ & + & + & 1 & - & 1 & 1 & 1 & 1 & 1 & & 1 & 1 & 1 & 1 \\
\hline s.ołeqnou! ssəu!sng & 一 & + & + & ' & $\sim$ & - & 1 & $\sim$ & $\mathrm{N}$ & 6 & $N$ & $\sim$ & in & $m$ & $r$ \\
\hline 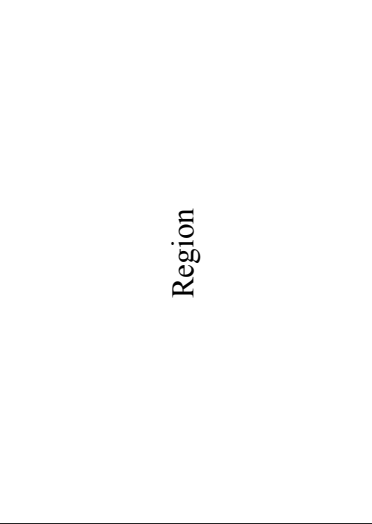 & $\varangle$ & 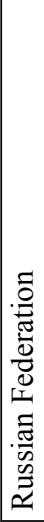 & 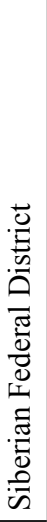 & 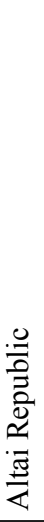 & 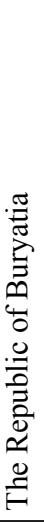 & 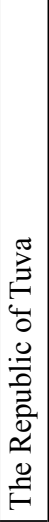 & 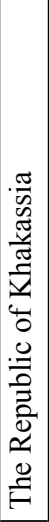 & 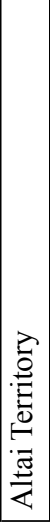 & 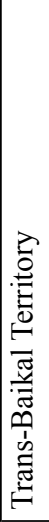 & 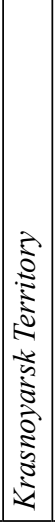 & 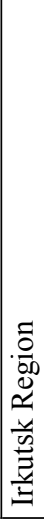 & 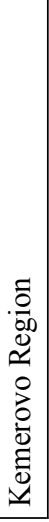 & 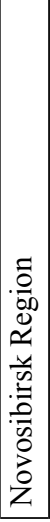 & 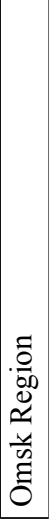 & 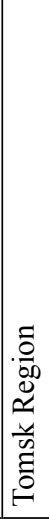 \\
\hline
\end{tabular}


social, informational, and becomes a factor for economic activity innovative transformation deterrence. Internal expenditure on research and development in relation to the gross regional product is an important factor of innovative development (Fig. 5).

During the considered period the analyzed indicator does not show a single trend in its dynamics. Thus, for the Russian Federation there is a decline in the period of 2006-2008, and growth in 2009-2012. Since 2005 the SFD in general is characterized by a positive tendency. The crisis manifestations of 2008 - 2009 did not affect the increase in the proportion and number of regions - the Republic of Buryatia and Tuva, the Krasnoyarsk Territory, Irkutsk, Novosibirsk and Tomsk regions. At that, abrupt fluctuations in indicators should be emphasized. Compared with the results of previous studies the presence of a significant gap in values is preserved: the minimum value is in the Trans-Baikal Territory $(0.14)$, the maximum one is in the Tomsk region (2.2). Preservation of vectors multidirectionality and increasing gaps in values reflects the similarity of the approach to the target-oriented programmes development to support research and development in virtually all the regions of the Siberian Federal District.

Apparently, the basis of multidirectional dynamics can be the fact that for non-innovative (according to the activity purpose) economic organizations, in the structure of costs, $R \& D$ are grouped as transaction ones and are immediately subjected to sequestering in case of the threat of reversal of trade. In this regard, only internal expenditures on innovation for the innovative organizations where they are regarded as interactional costs, ensuring the main production tasks fulfillment, are not sequestering. The rate of expenditure on technological innovation, calculated according to the method, gives opportunity to determine the level of engineering support upgrade. The proportion of expenditure in relation to GRP provides the opportunity to evaluate technological effectiveness of the produced regional product (Fig. 6).

The calculated values indicate approximation of the SFD regions to the nationwide figures, which has been demonstrating strong growth since 2009. Such dynamics, pointing both to the increase in the number and quality of technological conversions, probably reveal the trajectory of import substitution and increasing the capacity of export orientation of regional economic systems. The leading positions among the subjects of the district belong to the Tomsk and Irkutsk regions, the Krasnoyarsk and Trans-Baikal Territories, which indicators are higher than those of Russia. The Republics of Tuva and Khakassia are in the group of outsiders.

The territory susceptibility is determined, in particular, by the readiness to incorporate innovations into consumer and industrial practices that is undermined by the outflow of young and qualified cohort of potential employees (industrial innovations) and consumer (supporting innovation). The demographic situation, characterized by the preservation of the fall in the birth rate (largely determined by socioeconomic conditions and substitution of moral and ethical values in society), increased mortality rate, increase in the proportion of the retirementage population and presence of active migration continues to be important factors influencing the innovative susceptibility. There is fluctuation in the proportion of the economically active population in the total population in the analyzed periods. On average in 2010 - 2013 in the Russian Federation the rate is $52.1 \%$, in the Siberian Federal District $-51 \%$. More than $50 \%$ of the economically active population lives in the Omsk, Novosibirsk, Kemerovo and Irkutsk regions as well as in the Krasnoyarsk and Altai territories. The predominance of inactive population in the 


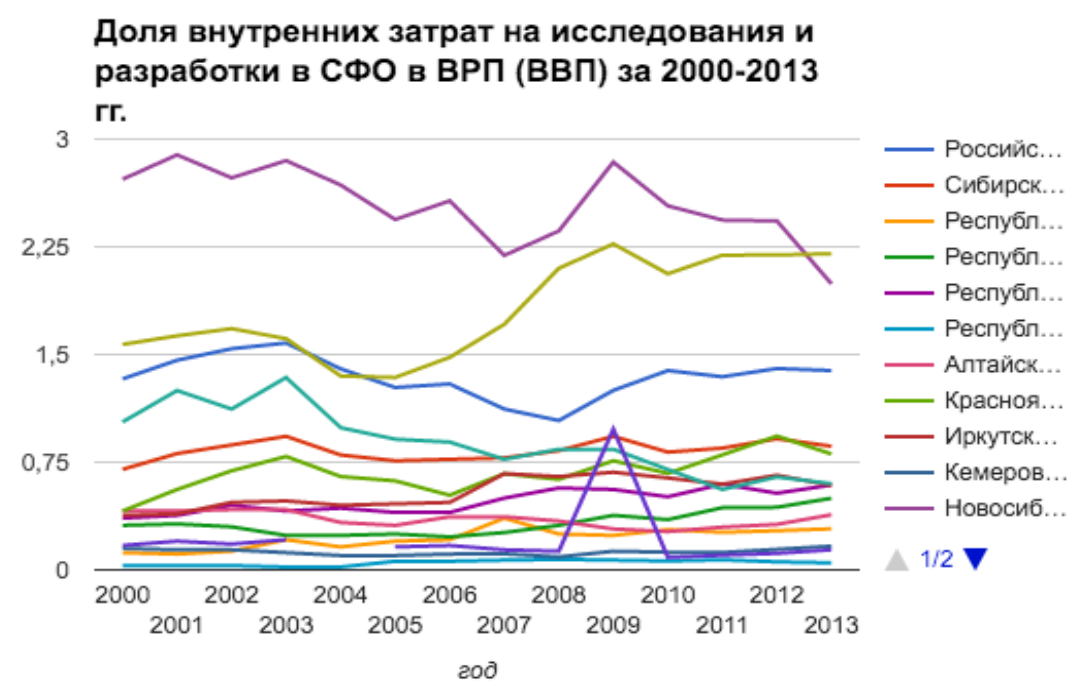

Fig. 5. The proportion of internal expenditure on research and development in the SFD in GRP (GDP) in 2000-2013

\section{Доля затрат на технологические инновации в СФО в ВРП (ВВП) за 2000-2013 гг.}

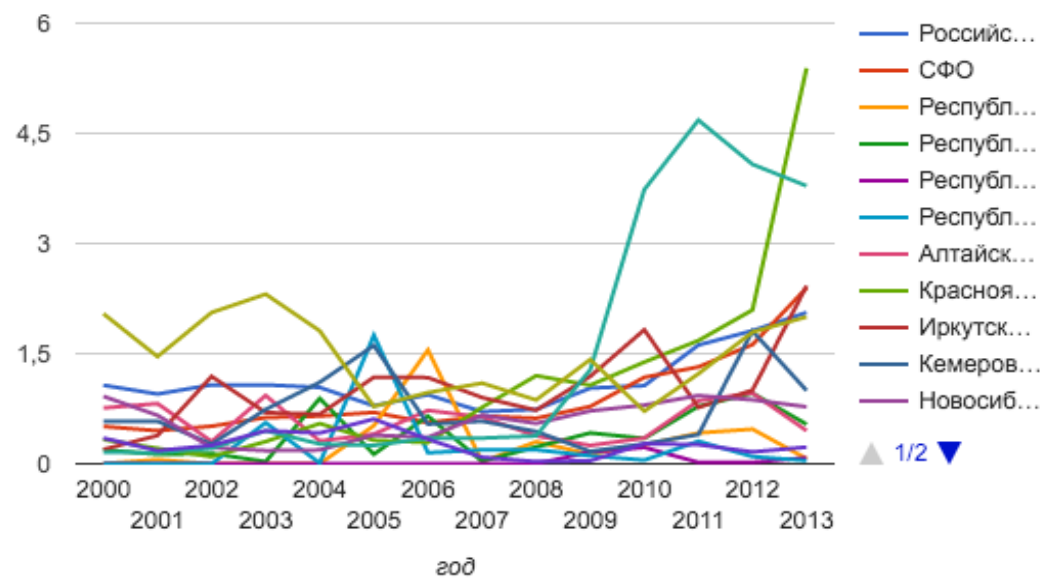

Fig. 6. The proportion of expenditure on technological innovation in the SFD in GRP (GDP) in 2000-2013

total population is typical of the Altai Republic, the Republics of Buryatia and Tuva.

Providing the effectiveness of innovation activity with the "triple helix" tools (Etzkowitz, 2010, Leydesdorff, 2006) has established the need for the institutional design of innovative environmental business practices. In the period of 2008 - 2013 the activation of law making in relation to innovation activities is observed (Table 2).

Inaccordance with the method of determining the innovative susceptibility of the region, institutional environment of innovation activity is of importance: the degree of normative innovative 
Table 2. Innovative legislation of the Russian Federation and the Siberian Federal District (01.01.2014)

\begin{tabular}{|c|c|c|c|c|c|c|}
\hline \multirow[t]{2}{*}{ Region } & \multicolumn{2}{|c|}{$\begin{array}{l}\text { Legislation in the field } \\
\text { of socio-economic } \\
\text { development }\end{array}$} & \multirow{2}{*}{$\begin{array}{c}\begin{array}{c}\text { Law regulation } \\
\text { innovation activity }\end{array} \\
\text { Law }\end{array}$} & \multicolumn{3}{|c|}{ Bylaws, regulating innovation sector } \\
\hline & Strategy & Programme & & Conception & Programme & Strategy \\
\hline Russian Federation & + & + & - & - & + & + \\
\hline $\begin{array}{l}\text { Siberian Federal } \\
\text { District }\end{array}$ & + & + & - & - & - & - \\
\hline Altai Republic & + & + & - & - & - & - \\
\hline $\begin{array}{l}\text { The Republic of } \\
\text { Buryatia }\end{array}$ & + & + & + & - & + & - \\
\hline The Republic of Tuva & + & + & + & + & + & + \\
\hline $\begin{array}{l}\text { The Republic of } \\
\text { Khakassia }\end{array}$ & + & + & + & + & + & - \\
\hline Altai Territory & + & + & + & - & - & + \\
\hline $\begin{array}{l}\text { Trans-Baikal } \\
\text { Territory }\end{array}$ & + & + & + & - & + & - \\
\hline Krasnoyarsk Territory & + & + & + & - & + & + \\
\hline Irkutsk Region & + & + & + & + & - & - \\
\hline Kemerovo Region & + & + & + & + & + & - \\
\hline Novosibirsk Region & + & + & + & + & + & - \\
\hline Omsk Region & + & + & + & + & - & - \\
\hline Tomsk Region & + & + & + & + & + & + \\
\hline
\end{tabular}

regulation elaboration. The Tomsk region, where the quality of institutional support for innovation is developing, is the leader: the current basic laws and regulations have undergone several revisions, the work in this direction is intensified in Altai Territory, Kemerovo and Omsk regions and the Republic of Tuva. In the Altai Republic and the Republic of Khakassia these issues are still paid little attention to.

The final picture of the long-term motivation to innovative ways of managing creates an idea of the relative intensity of the processes in the national economy, the SFD and its regions, confirming the significant differences of territorial innovation systems. The rating oscillation dynamics is characteristic even for steadily innovative areas (the Tomsk region), which confirms the uncertainty of innovation as an investment-type process. Significant differences in motivation to the innovative modernization of business processes indicate the requirement of taking into account the specificity of the innovation system fragments established in the territory in the course of the regional innovation policy. However, the very possibility of the regions ranking in terms of their innovation susceptibility reveals the possibility of a kind of tools typology and step by step stimulating of innovative processes of the regional economy. An important factor of increase in motivation becomes the difference in the level of innovative systems development in the region: it allows to use "follow the leader" approach with the adaptation of the proven themselves to be effective methods and tools for the innovation policy at the level of the SFD. The reference section contains interval data that give opportunity to aggregate the existing tendencies of innovative susceptibility. The results of the ranking in the form of the Matrix of the SFD regions distribution based on the level and rate of 
Table 3. The Matrix of the SFD regions innovative susceptibility*

\begin{tabular}{|c|c|c|c|c|}
\hline \multirow{2}{*}{$\begin{array}{l}\text { The rate of } \\
\text { change in } \\
\text { rating }\end{array}$} & \multicolumn{4}{|c|}{ Rating level } \\
\hline & High & Average & Satisfactory & Low \\
\hline $\begin{array}{l}\text { Highly } \\
\text { susceptible }\end{array}$ & $\begin{array}{l}\text { Tomsk } \\
\text { Region } \\
\text { Tomsk } \\
\text { Region } \\
1\end{array}$ & $\begin{array}{l}\text { Krasnoyarsk Territory, } \\
\text { Novosibirsk Region, } \\
\text { Omsk Region } \\
5\end{array}$ & $\begin{array}{l}\text { The Republic of } \\
\text { Buryatia, Trans-Baikal } \\
\text { Territory, } \\
\text { Krasnoyarsk Territory, } \\
\text { Irkutsk Region } \\
9\end{array}$ & $\begin{array}{l}\text { The Republic of Tuva, } \\
\text { Altai Republic, The } \\
\text { Republic of Khakassia } \\
\text { The Republic of Tuva, } \\
\text { Altai Republic, The } \\
\text { Republic of Khakassia } \\
13\end{array}$ \\
\hline $\begin{array}{l}\text { Moderately } \\
\text { susceptible }\end{array}$ & 2 & $\begin{array}{l}\text { Altai Territory, } \\
\text { Omsk Region } \\
6\end{array}$ & $\begin{array}{l}\text { The Republic of Buryatia, } \\
\text { Trans-Baikal Territory } \\
10\end{array}$ & 14 \\
\hline Susceptible & $\begin{array}{l}\text { Novosibirsk } \\
\text { Region } \\
3\end{array}$ & 7 & $\begin{array}{l}\text { Altai Territory, Kemerovo } \\
\text { Region } \\
11\end{array}$ & 15 \\
\hline $\begin{array}{l}\text { Lowly } \\
\text { susceptible }\end{array}$ & 4 & 8 & $\begin{array}{l}\text { Irkutsk Region, } \\
\text { Kemerovo Region } \\
12\end{array}$ & 16 \\
\hline
\end{tabular}

* Quadrants numbers are given in figures

change in the rating of innovative susceptibility (Table 3).

Greaterdemonstrativeness of the comparative dynamics of innovation susceptibility is achieved by bringing the rating data for the period of $2009-2013$ and situation in the interval of 20062009 (given in italics). The comparison shows that significant changes are not to be expected in innovative susceptibility of the region at the short interval. The regulatory instruments formation can not but rely on the similar properties of the administrative influence objects. An attempt to aggregate innovative characteristics on the basis of the rate and the level of innovation susceptibility reveals their inconsistency at the "high" and "average" levels at "susceptible" and "lowly susceptible" rates: qualitative characteristics of regional innovation systems, that were in these quadrants can be characterized by quite high uncertainty: either industry restrain of the innovation process (even under conditions of the implemented through nature of innovation), or stage restrain (only food, only technological, only organizational, etc.), or excessive territoriality of ongoing transformations (the absence of scalability required to initiate cluster mechanisms of innovation movement) could be quite possible barriers to claim on leadership positions. The above mentioned can be illustrated by a table reflecting variants for the monitoring data interpretation.

Based on combining the two indicators of rating evaluation and according to the methods, 5 groups of the SFD regions can be identified (Table 4).

An interpretative position selected by the regulator when choosing the strategy and tactics is not neutral; it affects the composition of tools and the nature of innovation motivation succession regulation. Giving priority to the characteristic of "quantitativehomogeneity of indicators "rate/level of innovation susceptibility" in the typological groups formation, we proceed from the assumption about the presence of a level of changes synchronization in innovation space, which is required for the multilevel regulatory impact effectiveness, aimed at the development of resource and product results of the economic process. 
Table 4. Comparative typology of innovative susceptibility of the SFD regions

\begin{tabular}{|l|l|l|l|l|l|l|}
\hline \multicolumn{2}{|c|}{ Groups of regions } & "Leaders" & $\begin{array}{l}\text { "Potential } \\
\text { leaders" }\end{array}$ & "Developing" & "Unstable" & $\begin{array}{l}\text { "Low } \\
\text { performing" }\end{array}$ \\
\hline $\begin{array}{l}\text { Territories' aggregates } \\
\text { depending on the } \\
\text { properties of innovation } \\
\text { systems interpretation }\end{array}$ & $\begin{array}{l}\text { Quantitative homogeneity } \\
\text { of indicators rate/level }\end{array}$ & $1-4$ & $5-6$ & 9,10 & $7,8,11,12$ & $13-16$ \\
\cline { 2 - 7 } & $\begin{array}{l}\text { Analytical homogeneity of } \\
\text { properties }\end{array}$ & $1,2,5,6$ & $3,4.7,8$ & 9,13 & $10,11,14,15$ & 12,16 \\
\hline
\end{tabular}

The group of "Leaders" is characterized by sustainable rates. The correctness of the groups' formation is indirectly confirmed by their behavior when the indicators change: in the group of "Leaders" in case of decline, the integrated index reduction is not lower than the average of its values for the period. The group of "Potential leaders" in case of the average rating level is characterized by the rate of change of not more than $10 \%$, compared with 2000-2007 all the groups strengthened their positions. The group of "Developing" moved to the quadrant of highly susceptible. The group of "Unstable" is characterized by multidirectional vectors of change and "Low performing" continues to demonstrate very low rating levels.

Thus, innovative susceptibility monitoring of the SFD regions allows stating the fact of increasing attention to the separate components of innovation activity (in particular, positive effects are observed in the field of legislative regulation). At the same time, negative tendencies are preserved in the other groups, which generally determine a relatively low level of innovative susceptibility.
Administrative influence tools. In this context, the validation of the possible tools for administrative influence on the part of state regional bodies involves understanding innovation processes deployment in the groups of similar regions. Table 5 provides typology of the nature of innovative susceptibility, implemented per totality of responding to changes on the part of all the studied parameters of the innovative systems of the regions for the period under study.

In the logic of the regulatory actions, based on the assumption that in each innovation oriented subject, the irreducible infrastructure minimum, capable to provide streaming and through nature of innovation as a resource-forming factor of economic growth should be formed, as well as goal-oriented innovation policy that reacts to the current level of its innovative susceptibility timely and appropriately in accordance with the state of innovation environment of the territory, based on the matrix approach in accordance with the key factors of innovation policy and the presence and maturity of innovative community, it is proposed to form a tool model of innovation policy, acceptable for the SFD regions. A characteristic

Table 5. Interrelation of the change in rating and the nature of innovative susceptibility

\begin{tabular}{|c|c|c|c|}
\hline \multirow{2}{*}{ Observed motivation manifestation to innovations } & \multicolumn{2}{|c|}{ Nature of innovative susceptibility } \\
\cline { 3 - 4 } & effective & ineffective & fictitious \\
\hline Group of susceptibility rating in measurement rate/level & $\begin{array}{l}\text { "leaders", } \\
\text { "possible leaders" }\end{array}$ & "Developing" "unstable", \\
"low performing"
\end{tabular}


Table 6. Matrix of tools for innovative regulation of the SFD regions*

\begin{tabular}{|c|c|c|c|c|c|}
\hline \multirow{2}{*}{$\begin{array}{c}\text { The rate of } \\
\text { change in rating }\end{array}$} & \multicolumn{4}{|c|}{$\begin{array}{l}\text { Rating level / recommended way and of composition of regulatory } \\
\text { tools }\end{array}$} & \multirow{2}{*}{$\begin{array}{l}\text { Key factor of } \\
\text { innovation policy }\end{array}$} \\
\hline & High & Average & Satisfactory & Low & \\
\hline \multirow{2}{*}{$\begin{array}{l}\text { Status/ } \\
\text { innovation } \\
\text { infrastructures } \\
\text { presence }\end{array}$} & \multicolumn{2}{|c|}{ Innovative society } & \multicolumn{2}{|c|}{ Innovative environment } & \\
\hline & $\begin{array}{l}\text { Environment } \\
\text { for through } \\
\text { innovation } \\
\text { support }\end{array}$ & $\begin{array}{l}\text { More than } \\
\text { three business } \\
\text { incubators } \\
\text { more than two } \\
\text { universities, SB } \\
\text { RAS centre }\end{array}$ & $\begin{array}{l}\text { Business } \\
\text { incubator, } \\
\text { communication } \\
\text { ground }\end{array}$ & \begin{tabular}{|l} 
Singular \\
fragment of \\
innovative \\
infrastructure
\end{tabular} & $\begin{array}{l}\text { Tools to provide } \\
\text { cluster connections in } \\
\text { the innovative sector } \\
\text { of territorial economy }\end{array}$ \\
\hline $\begin{array}{l}\text { Highly } \\
\text { susceptible }\end{array}$ & $\begin{array}{l}1 \text { "sustainable } \\
\text { network": }\end{array}$ & $\begin{array}{l}5 \text { "network } \\
\text { teambuilding": }\end{array}$ & $\begin{array}{l}\text { 9"weak } \\
\text { network": }\end{array}$ & $\begin{array}{l}13 \text { "window to } \\
\text { the world": }\end{array}$ & capitalization \\
\hline $\begin{array}{l}\text { Moderately } \\
\text { susceptible }\end{array}$ & $\begin{array}{l}2 \text { "network } \\
\text { communication } \\
\text { initiation": }\end{array}$ & $\begin{array}{l}\text { "through } \\
\text { teambuilding": }\end{array}$ & $\begin{array}{l}10 \text { "space } \\
\text { initiation" }\end{array}$ & $\begin{array}{l}14 \text { "the first } \\
\text { signs": }\end{array}$ & $\begin{array}{l}\text { interaction } \\
\text { technification }\end{array}$ \\
\hline Susceptible & $\begin{array}{l}3 \text { "territorial } \\
\text { innovation } \\
\text { ground": }\end{array}$ & $\begin{array}{l}7 \text { “project } \\
\text { teambuilding”: }\end{array}$ & $\begin{array}{l}11 \text { "space } \\
\text { initiation" }\end{array}$ & $\begin{array}{l}15 \text { "growing } \\
\text { point" }\end{array}$ & $\begin{array}{l}\text { development of } \\
\text { institutes generating } \\
\text { innovations }\end{array}$ \\
\hline $\begin{array}{l}\text { Lowly } \\
\text { susceptible }\end{array}$ & $\begin{array}{l}4 \text { “innovative } \\
\text { educational } \\
\text { system”: }\end{array}$ & \begin{tabular}{|l}
8 \\
"projects \\
initiation"
\end{tabular} & $\begin{array}{l}12 \\
\text { "communication } \\
\text { initiation" }\end{array}$ & $\begin{array}{l}16 \\
\text { "initiation of } \\
\text { cooperation } \\
\text { motivation" }\end{array}$ & $\begin{array}{l}\text { informational } \\
\text { policy: formation } \\
\text { of the symbolic } \\
\text { capital of innovative } \\
\text { environment }\end{array}$ \\
\hline
\end{tabular}

of the regulatory action method as a rising in complexity model is given in Table 6 .

For example, evolution of the regulatory system at the stage of capitalization under conditions of different maturity of the innovation system components can be represented by a landmark ascent in the complexity of the regulated processes in the following way: from the development of the innovators' industry interaction ("window to the world") through providing regularity of horizontal interaction and the search for vertical integration ("weak network"), on the basis on the interpersonal trust formation ("network teambuilding") to the continuity of interaction in the innovation system ("sustainable network"). The apparent fragility of the innovation system, provided at the initial stages of its formation (position in the right quadrants of the matrix), which is a consequence of the absence of practices and high uncertainty in the success of practical application of innovations requires an emphasis on informational and reputational components (understood as investments into the symbolic capital of the territorial economic system).

\section{Conclusion}

Relevance of the value of innovation as a resource condition for economic development, especially relevant in the case of limited access to the traditional sources of providing sustainability of the economic system of Russia requires the formation of streaming (continuous) nature of resource provision. Availability of human resources capital that forms innovation in general, as well as territorial economic system in particular, requires succession of conditions contributing to the sustainable achievement motivation formation (constructive for economic development). In this context, the tools of precise and accurate "tuning" of the national and territorial innovation systems, 
their compliance with the actual level of innovation and, consequently, socio-economic development acquire relevance. The possibility to express the region's motivation quality to use the transformational potential of the resources available to it and expanding the borders of interaction (both in the direction of "resources/ products" and in the direction of "organization/ technology") through the rates of innovative susceptibility facilitates the selection of the regulation measures adequate to the tasks to increase the level of technological structure, breakthrough use of the found solutions and creation of economic mechanisms of the advanced (but not catching up) type. It is the main expected benefit from innovation.

\section{References}

Anokhin, P.K. (1978). Filosofskie aspekty teorii funktsional'noi sistemy. Izbrannye trudy [Philosophical Aspects of the Functional Systems Theory. Selected Works], 399 p.

Baburin, V.L. (2002). Innovatsionnye tsykly v rossiiskoi ekonomike [Innovative Cycles in Russian Economy], 120 p.

Batishchev, G.S. (1990). Neischerpannye vozmozhnosti $i$ granitsy primenimosti kategorii deiatel'nosti. Deiatel'nostnyi podkhod v plenu substantsionalizma. Ne deianiem edinym zhiv chelovek. Deiatel'nost': teorii, metodologiia, problemy [Infinite Possibilities and Boundaries of the Activity Category Applicability. Activity Approach in the Grip of Substantionalism. Man Does not Live by the Action Alone. Activity: Theories, Methods, Challenges].

Biznes ne predlagat'. Statistika fiksiruet stabil'noe snizhenie interesa k predprimatel'stvu [Do not Offer Business. Statistics Evidences Stable Decrease in Interest to Entrepreneurship] (2006), In Vedomosti [Bulletin] [Electronic Source]. Available at: http://www.vedomosti.ru/opinion/ articles/2016/02/11/628496-biznes-ne-predlagat.

Vladimirova, O.N. (2011). Innovatsionnaia vospriimchivost' regiona: usloviia formirovaniia $i$ upravlenie [Innovative Susceptibility of the Region: Formation Conditions and Management]. Krasnoyarsk State Institute of Trade and Economics, Krasnoyarsk, 146 p.

Vladimirova, O.N. (2010). Metodicheskie podkhody $\mathrm{k}$ formirovaniiu reitinga innovatsioinnovatsionnoi vospriimchivosti regiona [Methodical Approaches to the Innovative Susceptibility of the Region Rating Formation], In Initsiativy XXI veka [Initiatives of the 21 ${ }^{\text {st }}$ Century], 4-5, 68-73.

Vladimirova, O.N.(2012). Teoreticheskie imetodicheskie aspekty otsenkiinnovatsioinnovatsionnoi vospriimchivosti regiona [Theoretical and Methodical Aspects of the Innovative Susceptibility of the Region Assessment], In Ekonomicheskii analiz: teoriia i praktika [Economic Analysis: Theory and Practice], 16, 40-53.

Vladimirova, O.N. (2013). Monitoring innovatsionnoi vospriimchivosti regiona: osnovnye tendentsii [Monitoring of the Innovative Susceptibility of the Region: Major Tendencies], In Regional'naia ekonomika: teoria i praktika [Regional Economy: Theory and Practice], 30, 2-11.

Vladimirova, O.N. (2015). Monitoring innovatsionnoi vospriimchivosti regionov Sibirskogo Federal'nogo Okruga [Monitoring of the Siberian Federal District Regions' Innovative Susceptibility], In Nauka i praktika [Science and Practice], 2 (18), 47-53.

Davydov, V.V. (1996). Teoria razvivaiushchego obucheniia [Development Teaching Theory]. INTOR, $544 \mathrm{p}$. 
Dvizhenie regionov Rossii k innovatsionnoi ekonomike [Movement of Russian Regions to the Innovative Economy] (2006). Edited by A.G. Granberg, S.D. Velentei, 402 p.

Ilyenkov, E.V. (1984). Dialekticheskaia logika: Ocherki teorii i istorii [Dialectical Logic: Essays on Theory and History], $320 \mathrm{p}$.

Etzkowitz, H. (2010). Innovarsii v deistvii [The Triple Helix: University-Industry-Government Innovation in Action]; translated from English under the editorship of A.F. Uvarov, Tomsk, 238 p.

Biznes ne predlagat'. Statistika fiksiruet stabil'noe snizhenie interesa k predprimatel'stvu [Do not Offer Business. Statistics Evidences Stable Decrease in Interest to Entrepreneurship], In Vedomosti [Bulletin], [Electronic Source], Available at: http://www.vedomosti.ru/opinion/ articles/2016/02/11/628496-biznes-ne-predlagat

Leontiev, A.N. (1977). Deiatel'nost'. Soznanie. Lichnost' [Activity. Consciousness. Personality]. 304 p.

Malakhovskaya, M.V. (2000). Logika motivatsii khoziaistvuiushchego sub'ekta [Logics of the Economic Subject Motivation]. 162 p.

Malakhovskaya, M.V., Skryl'nikova, N.A. (2009). Formirovanie motivatsii k sozdaniiu inoovatsionnoi ekonomiki v Rossii [Formation Motivation to Creation of the Innovative Economy in Russia], In Vestnik Tomskogo gosudarstvennogo universiteta. Ekonomika [Tomsk State University Bulletin. Economics]. Экономика, 1, 24-38.

Nauka i innovatsii v regione [Science and Innovations in the Region]. [Electronic Source], Available at: http://regions.extech/ru

Natsional'nyi doklad ob innovatsiiakh v Rossii 2015. Proekt. [National Report on Innovation in Russia 2015. Project]. [Electronic Source], Available at: http://www.rusventure.ru/ru/programm/ analytics/docs/NROI_RVC.pdf

Natsional'naia innovatsionnaia sistema gosudarstvennai innovatsionnaia politika Rossiiskoi Federatsii (2000): Bazovyyi doklad k obzory OESR natsional'noi innovatsionnoi sistemy Rossiiskoi Federatsii [National Innovative System and National Innovation Policy of the Russian Federation (2000): Background Report to the OECD Country Review of the Russian Innovation Policy]. [Electronic Source], Available at: www. mon.gov.ru/press/news/6333

European Commission (2014) Regional Innovation Scoreboard 2014. [Electronic Source], Available at: http://ec.europa.eu/enterprise/policies/innovation/files/ris/ris-2014_en.pdf

Parsons, T. (2000). O structure sotsial'nogo deistviia [The Structure of Social Action], 880 p.

Regiony Rossii. Sotsial'no-ekonomicheskie pokazateli (2015) [The Regions of Russia. Social and Economic Indicators (2015)]. Rosstat, 1266 p.

Reiting innovatsionnogo razvitia sub'ektov Rossiiskoi Federatsii (2015) [Rating of Innovative Development of the Russian Federation Subjects (2015)], 3, under the editorship of L.M. Gokhberg, National Research University "Higher School of Economics", 248 p.

Rossiaiane svykaiutsia s mysl'iu o zatiazhnom krizise (2016) [Russians Get Used to the Idea of Protracted Crisis (2016)] "Levada Center", In Vedomosti [Bulletin], [Electronic Source], Available at: $\quad$ http://www.vedomosti.ru/politics/articles/2016/02/12/628697-rossiyane-svikayutsya-mislyuzatyazhnom-krizise-levada-tsentr

Shchedrovitsky, G.P. (2005-2008). Znak i Deiatel'nost' [Sign and Activity], 1400 p.

Yudin, E.G. (1997). Metodoloogia nauki. Sistemnost'. Deiatel'nost'. [Science Methodology. Systematic Character. Activity], 444 p. 
Leydesdorff, L.(2006). The Knowledge-Based Economy: Modeled, Measured, Simulated. Universal Publishers Boca Raton, Florida, USA, 2006.

\author{
Динамика инновационной \\ восприимчивости регионов \\ Сибирского федерального округа \\ в контексте рейтинга \\ инновационного развития субъектов \\ Российской Федерации в 2000-2013 годах
}

\author{
О.Н. Владимирова, М.В. Малаховская \\ Сибирский федеральный университет \\ Россия, 660041, Красноярск, пр. Свободный, 79
}

\begin{abstract}
Возможность управления инновациями обеспечивается учетом закономерностей территориально укорененной инновационной системы. В практике сравнительного анализа инновачионности стран и регионов используются методики оценки конкурентоспособности Всемирного экономического форума, методика Комиссии европейских сообществ (КЕС), методика Организации экономического сотрудничества и развития (ОЭСР), методика Американского научного фонда (NCF). В отечественной литературе имеются: типизация регионов России и ближнего зарубежья по степени развития инновачионного потенциала и масштабам инновационной деятельности В. Л. Бабурина (Бабурин, 2002); типологизация по инновационному потенциалу на основе дисперсионного анализа и экспертных оценок Н. Н. Волкова, Н. И. Маркова (Движение регионов...,2006), модель российского регионального инновационного индекса (исследовательский университет ВШЭ) (Рейтинг инноваиионного.., 2015) и группировка регионов методом индекса инновационности (Доклад к обзору ОЭСР, 2000). Статистика регионов СФО, в том числе общая экономическая и специильная за период 2000-2013 г2. в сравнении с состоянием показателей инновационной деятельности РФ обнаружсивает недостаточность уровня и динамики индикаторов инновационного развития (Владимирова, 2013). Так, доля инновационной продукияии в России в общем выпуске составляет 8-9 \% (в странах-лидерах этот показатель около $15 \%$ \%) и, по данным за последние 3 года, не растет. Результаты российских инноваций обладают низкой конкурентоспособностью: доля России в общем мировом экспорте высокотехнологичных товаров - 0,4 \% (Национальный доклад, 2015), что свидетельствует о необходимости безотлагательных усилий по преобразованию регуляторных механизмов и инструментов в направлении повышения связанности и взаимной поддерживаемости компонентов инновационных систем территорий.
\end{abstract}

Ключевые слова: инновационная восприимчивость региона, список рейтинга инновационной восприимчивости региона, субъекты Сибирского федерального округа.

Научная специальность: 08.00.00 - экономические науки. 